\title{
Downs syndrome and its screening: how aware are we?
}

\author{
Murli Krishna Nambiar, Roopa P. S.*, Nisha C., Pratap Kumar
}

Department of Obstetrics and Gynecology, Kasturba Medical College, Manipal Academy of Higher Education, Manipal, Karnataka, India

Received: 11 January 2018

Accepted: 10 February 2018

\section{*Correspondence:}

Dr. Roopa P. S.,

E-mail: roopasarun@gmail.com

Copyright: ( $)$ the author(s), publisher and licensee Medip Academy. This is an open-access article distributed under the terms of the Creative Commons Attribution Non-Commercial License, which permits unrestricted non-commercial use, distribution, and reproduction in any medium, provided the original work is properly cited.

\section{ABSTRACT}

Background: Down syndrome (DS) is the most common chromosomal abnormality found in live-born babies. The objectives of this study were to assess the knowledge, attitude and practices of pregnant women regarding Down syndrome and its screening.

Methods: This was a prospective study done in the Department of Obstetrics and Gynecology, in a tertiary care hospital. All pregnant ladies who attended the antenatal clinic and consented for the study were included. A prevalidated questionnaire was given to these women and data was collected. Responses to pregnant women's knowledge, attitudes and practices were evaluated in a three-point scale of yes/no/ don't know. All correct answers or all but one correct answer was scored good and the percentage was calculated.

Results: A total of 267 pregnant women were included in the study. Of the 267 women only $156(58.4 \%)$ had heard about Down syndrome. Eighty five percent of the women unanimously agreed that Down syndrome babies had mental impairment. But only $21.1 \%$ patients had good knowledge score on Down syndrome. Eleven percent had good knowledge regarding Down syndrome screening tests. Almost sixty five percent of the women had the right attitude towards screening tests and $46.1 \%$ patients had followed good practice.

Conclusions: Informed decision making rather than imposed decision making must be practiced. Compulsory and effective education regarding Down syndrome and its screening must be provided to all patients at the earliest antenatal visit. The gap between women's knowledge, theirs attitudes and practice has to be addressed to. Noninvasive prenatal testing might be the future and is quickly bring about a shift in the paradigm in prenatal screening.

Keywords: Awareness, Downs syndrome screening, Knowledge attitude practices in Down syndrome screening

\section{INTRODUCTION}

Down syndrome (DS) is the most common chromosomal abnormality found in liveborn babies. ${ }^{1}$ In this condition there is an extra chromosome in chromosome 21 . Hence it is commonly called as trisomy 21 . DS was discovered by Down JL in $1866 .{ }^{2}$ Its incidence increases with the increasing age of the mother at delivery. In the 30 s the incidence might be 1:800 falling to 1:350 at 35 years of age. It might result due to non-dysjunction (95\%), translocation (4\%) and mosaicism. ${ }^{2}$ A number of abnormalities are associated with Down syndrome, the commonest association being various degrees of intellectual disability. The IQ many range anywhere between as low as 20 to as high as 70 depending on the severity of mental retardation. ${ }^{3}$ Cardiac abnormalities, gastrointestinal abnormalities, obesity, eye problems, endocrine, hearing loss are the other abnormalities associated, to name a few.

The screening for DS has evolved over the years. It has shifted from just maternal age being the parameter for risk assessment to various biochemical markers and ultrasound modalities. First trimester screening tests are available and have now replaced second trimester screening. Detection rates have improved, and false 
positive rates have fallen. All these screening tests have a $5 \%$ false positive rate. ${ }^{4,5}$

In our hospital we offer the combined test from 11 to 13 weeks 6 days. Here we do the dual testing (which includes b-HCG and PAPP-A) with nuchal translucency (NT) together to assess the risk. Combined test has $90 \%$ sensitivity and $95 \%$ specificity for detection of Down syndrome. ${ }^{6}$ Screening is offered to all women regardless of their age and done for those who have opted for the test. $^{7}$

The aim of the present study was to assess the knowledge, attitude and practices of pregnant women regarding Down syndrome and its screening.

\section{METHODS}

This was a prospective study done in the Department of Obstetrics and Gynecology, in a tertiary care hospital. All pregnant ladies who attended the antenatal clinic and consented for the study were included. The pregnant women's willingness to participate in the study was taken as a proof of consent. A pre-validated questionnaire (from 2 obstetricians, 2 pediatricians and one geneticist) was given to these women and data was collected.

The questionnaire included demographic details of the women, (in terms of parity, age, gestational age, educational status) knowledge regarding Down syndrome and its screening, incorporating 6 questions each, 4 questions regarding attitudes and one question on practice.

A total of 17 questions were included in the questionnaire, excluding the demographic details. Responses to pregnant women's knowledge, attitudes and practices were evaluated in a three-point scale of yes/no/don't know. All correct answers or all but one correct answers were scored good and the percentage was calculated. Institutional ethical committee clearance was obtained.

\section{RESULTS}

A total of 267 pregnant women were included in the study.

Table 1 shows the demographic profile of the women enrolled in the study. In assessing the knowledge, importance of educational status of the women cannot be exaggerated. Around $61.4 \%$ of the women were either a graduate or had finished their secondary schooling. Of the 267 women only 156 (58.4\%) had heard about Down syndrome. The remaining results were analyzed on the 156 women who knew about Down syndrome.

Table 2 analyzed the knowledge regarding Down syndrome. When assessing their in-depth knowledge, we found it seriously lacking. Eighty five percent of the women unanimously agreed that Down syndrome babies had mental impairment. But only $33(21.1 \%)$ out of the 156 patients had good knowledge score on Down syndrome (that is only 33 women could answer either all the questions correctly or only one question was answered wrong).

Table 1: Demographic details of the women enrolled in the study.

\begin{tabular}{|c|c|}
\hline $\begin{array}{l}\text { Demographic details of the } \\
\text { women included in the study }\end{array}$ & $\mathrm{n}=267(\%)$ \\
\hline \multicolumn{2}{|l|}{ Parity } \\
\hline Primi & $154(57.7)$ \\
\hline Multi & $113(42.3)$ \\
\hline \multicolumn{2}{|l|}{ Gestation } \\
\hline $1^{\text {st }}$ trimester & $28(10.5)$ \\
\hline $2^{\text {nd }}$ trimester & $109(40.8)$ \\
\hline $3^{\text {rd }}$ trimester & $130(48.7)$ \\
\hline \multicolumn{2}{|l|}{ Age } \\
\hline$<25$ years & $45(16.8)$ \\
\hline $26-30$ years & $149(55.8)$ \\
\hline $31-35$ years & $67(25.2)$ \\
\hline$>35$ years & $6(2.2)$ \\
\hline \multicolumn{2}{|l|}{ Education } \\
\hline Primary & $36(13.5)$ \\
\hline SSLC & $67(25.1)$ \\
\hline PUC & $95(35.6)$ \\
\hline Graduate & $69(25.8)$ \\
\hline H/O Down syndrome in family & $12(4.5)$ \\
\hline $\begin{array}{l}\mathrm{H} / \mathrm{O} \text { previous baby affected with } \\
\text { Down syndrome }\end{array}$ & $15(5.6)$ \\
\hline
\end{tabular}

Table 2: Frequency (\%) of correct answers to individual question with regards to knowledge on Down syndrome.

\begin{tabular}{|c|c|}
\hline Knowledge regarding Down syndrome & $\begin{array}{l}\mathrm{n}=\mathbf{1 5 6} \\
(\%)\end{array}$ \\
\hline Down syndrome is a genetic abnormality & $70(44.8)$ \\
\hline $\begin{array}{l}\text { Children with Down syndrome have } \\
\text { mental impairment }\end{array}$ & $134(85.8)$ \\
\hline $\begin{array}{l}\text { Down babies have other abnormalities } \\
\text { other than mental impairment }\end{array}$ & $118(75.6)$ \\
\hline $\begin{array}{l}\text { The chance of having a baby with Down's } \\
\text { syndrome is higher in the older mother }\end{array}$ & $126(80.7)$ \\
\hline $\begin{array}{l}\text { A previous baby with Down syndrome } \\
\text { increases the chance of Down syndrome } \\
\text { in this pregnancy }\end{array}$ & $81(51.9)$ \\
\hline Is Downs syndrome treatable? & $85(54.4)$ \\
\hline
\end{tabular}

Table 3 assesses the knowledge regarding the screening test. We assessed the knowledge of the screening tests in general and found it to be poor. Only 18 (11.5\%) out of the 156 patients had good knowledge regarding Down syndrome screening tests.

Table 4 shows the attitude and practise of women regarding the screening tests available. Though the 
knowledge of both, Down syndrome and its screening was deficient, the attitudes and practices of the women were good. $101(64.7 \%)$ of the women had the right attitude towards screening tests. Seventy-two (46.1\%) out of the 156 patients had followed good practise.

Table 3: Frequency $(\%)$ of correct answers with regards to questions on knowledge of screening tests available for Downs syndrome.

\begin{tabular}{|c|c|}
\hline Knowledge regarding screening & $n=156(\%)$ \\
\hline $\begin{array}{l}\text { The possibility of having Down } \\
\text { syndrome can be predicted by doing } \\
\text { certain blood tests along with } \\
\text { ultrasound in the mother }\end{array}$ & $127(81.4)$ \\
\hline $\begin{array}{l}\text { It is done ideally in first four months of } \\
\text { pregnancy }\end{array}$ & $131(83.9)$ \\
\hline $\begin{array}{l}\text { Preliminary blood test in the mother is } \\
\text { positive means the baby is definitely } \\
\text { suffering from Down syndrome }\end{array}$ & $69(44.2)$ \\
\hline $\begin{array}{l}\text { Preliminary blood test in the mother } \\
\text { can be negative, when the baby actually } \\
\text { suffers from Down syndrome }\end{array}$ & $69(44.2)$ \\
\hline $\begin{array}{l}\text { Should the result of the test be } \\
\text { negative, the child is always normal }\end{array}$ & $78(50)$ \\
\hline $\begin{array}{l}\text { Termination is possible if down } \\
\text { syndrome is detected in } 1^{\text {st }} \text { four months } \\
\text { of pregnancy }\end{array}$ & $121(77.5)$ \\
\hline
\end{tabular}

Table 4: Frequency (\%) of right attitudes and good practices regarding Down syndrome and its screening tests.

\begin{tabular}{|ll|}
\hline $\begin{array}{l}\text { Attitude } \\
\text { Will you undergo test to detect down } \\
\text { syndrome }\end{array}$ & $\begin{array}{l}\text { Right attitude } \\
n=156(\%)\end{array}$ \\
\hline $\begin{array}{l}\text { If your previous child is having down } \\
\text { syndrome will you undergo screening } \\
\text { test }\end{array}$ & $132(84.3)$ \\
\hline $\begin{array}{l}\text { If preliminary maternal test is } \\
\text { positive for down syndrome will you } \\
\text { undergo amniocentesis/CVS? }\end{array}$ & $132(84.6)$ \\
\hline $\begin{array}{l}\text { If the result of the test comes } \\
\text { positive, will you undergo abortion? }\end{array}$ & $106(67.9)$ \\
\hline $\begin{array}{l}\text { Practice } \\
\text { Have you ever undergone tests to } \\
\text { detect down syndrome }\end{array}$ & $\begin{array}{l}\text { Right practice } \\
\mathbf{n}=\mathbf{1 5 6}(\%)\end{array}$ \\
\hline
\end{tabular}

\section{DISCUSSION}

This was the first study done in Dakshina Kannada district to assess the knowledge of Down syndrome and its screening. Ours is a tertiary care hospital where prenatal screening is offered routinely. We have high risk pregnancy clinic, fetal medicine specialist and geneticist in our hospital. We perform first trimester, second trimester screening with both biochemical markers and ultrasound modalities routinely and have options of chorionic villus sampling (CVS), amniocentesis and percutaneous umbilical blood sampling (PUBS). Though the incidence of DS is higher in elderly women (>35 years), $80 \%$ of the Down syndrome children are born to woman under 35 years age.

The prevalence of Down syndrome is predicted to be 1:634 in the absence of selective pregnancy termination which is relatively high. ${ }^{1}$ The incidence of DS is rising now with increasing number of couples postponing pregnancy, the prevalence of DS is estimated to climb. ${ }^{8}$ There is a significant morbidity on the affected individual and the family both financially and emotionally depending on the degree of affliction.

In India, Medical Termination of pregnancy (MTP) is legalized up to 20 weeks of gestation. ${ }^{9}$ So if the screening test is positive, we have an option of doing amniocentesis/CVS to confirm the diagnosis and if the couples wish can terminate the pregnancy. Or she can continue the pregnancy and sought the help of support groups and specialists who can prepare the parents and the family for the care of DS baby and also take aid financially. ${ }^{10}$

Due to the advances in medicine and availability of corrective heart surgeries the life expectancy of children with Down syndrome has increased from the 1960s era. Now on an average, persons with DS live up to 50 years. ${ }^{11}$ So it becomes important for the pregnant women to know the options available for prenatal testing and decide on a suitable management.

The screening tests available are non-invasive, easy to perform, and can be incorporated in daily antenatal clinics. For a basic understanding, a minimal education is sufficient. But it suffices to say that this basic knowledge and understanding might help a family either to circumvent or adopt strategies to plan their pregnancy.

By this study, we have come to the conclusion that knowledge of both the Downs syndrome and screening tests available for it, are poor in our population $(21.1 \%$, $11.5 \%$ respectively). This is comparable to a study done in North India where $14.2 \%$ were aware about triple test and $16.6 \%$ accepted the test. ${ }^{12}$ In the present study, $64.7 \%$ of the women had right attitude towards screening tests. Seventy-two $(46.1 \%)$ out of the 156 patients had undergone the test despite poor knowledge of Down syndrome and its screening. This is comparable to other studies which showed positive attitudes, in spite of poor knowledge about prenatal screening. ${ }^{13,14}$

We found that the patients educational status did not guarantee good awareness about Down syndrome and the screening test. This is in contrast to another study which showed that higher education positively affected the knowledge of DS. ${ }^{15}$ There was no correlation between the parity and age, with knowledge. ${ }^{16}$ When we considered women with family history of Down syndrome and 
previous baby with Down syndrome we found that eight of the 12 women $(66.6 \%)$ had good knowledge of Down syndrome and 9 out of the 15 women $(60 \%)$ in women with previous history of Down syndrome had good knowledge of DS, but the methods available for screening was still not well understood. A personal experience with a Down syndrome baby, either with a previous baby or a family history increased the drive and awareness of the pregnant women and their family to know more about this condition and likewise their knowledge of this condition was comparatively better. But the screening tests available were still an area which was beyond their grasp, either due to low literacy or poor counselling. This is comparable to another study which showed that though women were able to understand the general concept of screening when asked about the intricacies of the screening test they were found lacking. ${ }^{17}$

There is a gap between women's knowledge and their attitudes and practise. This might point towards imposed decision making, as opposed to informed decision making which should be the goal.

This can be achieved by providing adequate information to the pregnant woman and her partner regarding Down syndrome and the test. This does not mean that more and more of pregnant patients should take up the screening test, but they should be aware of them, and we should make them proficient enough to make an autonomous decision to either take part in the testing or opt out, after considering all the risks and benefits. This may also help them to prepare for the eventuality of going through amniocentesis if they screen positive.

In India MTP has been legalized up to 20 weeks. We have a confirmatory test, which is the amniocentesis, if the woman is screened positive. So, this testing becomes more important as the affected women have an option of terminating the pregnancy if the diagnosis is confirmed.

There has been a recent proposal to include non-invasive prenatal testing as a screening test wherein cell free DNA of the foetus in the mother is assessed. ${ }^{18}$ It offers an intermediate step between screening and a diagnostic test. This might be the future and is swiftly bringing about a shift in the prenatal testing paradigm.

\section{CONCLUSION}

Informed decision making rather than imposed decision making must be practiced. Compulsory and effective education regarding Down syndrome and its screening must be provided to all patients at the earliest antenatal visit. The gap between women's knowledge and theirs attitudes and practice has to be addressed to. Noninvasive prenatal testing might be the future and is quickly bring about a shift in the paradigm in prenatal screening.

Funding: No funding sources
Conflict of interest: None declared

Ethical approval: The study was approved by the Institutional Ethics Committee

\section{REFERENCES}

1. Ostermaier KK. Down syndrome: Clinical features and diagnosis. In: Rose BD, ed. UpToDate. Welleseley, MA: UpToDate; 2010.

2. National Down syndrome society. Available at www.nads.org

3. Bull MJ. Committee on genetics. Health supervision in children with Down syndrome. Pediatr. 2011;128:393.

4. Driscoll DA, Gross SJ. Professional practice guidelines committee. Screening for fetal aneuploidy and neural tube defects. Genet Med. 2009;11(11):818-21.

5. Malone F, Canick JA, Ball RH. First trimester or second-trimester screening or both for Down's syndrome. First and Second-Trimester Evaluation of Risk (FASTER) research consortium. N Engl J Med. 2005;353(19):2001-11.

6. Hyett J. Noninvasive prenatal testing for Down syndrome. Aust Prescr. 2014;37:51-5.

7. ACOG Committee on Practice Bulletins. Screening for fetal chromosomal abnormalities, ACOG practice Bulletin No 77. Obstet Gynecol. 2007;217:109-202.

8. Shin M, Besser LM, Kucik JE, Lu C, Siffel C, Correa A. Congenital anomaly multistate prevalence and survival collaborative. Prevalence of Down syndrome among children and adolescents in 10 regions of the United States. Pediatr. 2009;124(6): 1565-71.

9. Government of India. Department of Family Welfare. MTP act 1971. Available at lawmin.nic.in

10. Down syndrome federation of India. Available at www.downsyndrome.in

11. Presson AP, Partyka G, Jensen KM, Devine OJ, Rasmussen SA, McCabe LL, et al. Current estimate of Down syndrome population prevalence in the United States. J Pediatr. 2013;163(4):1163-8.

12. Baxi A, Kaushal M. Awareness and Acceptability in Indian women of triple test screening for Down's syndrome. Internet J Gynecol Obstet. 2007;9(2).

13. Shalaby HAR, Elhady RA, Gamal AM, Badry AA. Prenatal diagnosis in low resource setting: Is it acceptable? J Obstet Gynecol India. 2012;62(5):5159.

14. Belahcen A, Taloubi M, Chala S, Izgua AT, Alaoui AM. Mother's awareness and attitudes towards prenatal screening for Down syndrome in Muslim Moroccans. Prenatal Diagnosis. 2014;34:821-30.

15. Pruksanusak N1, Suwanrath C, Kor-Anantakul O, Prasartwanakit V, Leetanaporn R, Suntharasaj T, Hanprasertpong T. A survey of the knowledge and attitudes of pregnant Thai women towards Down syndrome screening. J Obstet Gynaecol Res. 2009 Oct; 35(5):876-81. 
16. Gidiri M, Holding S, Lindow SW. Reduction in Down's syndrome screening acceptance is predominantly observed in women aged 25-35 years. Womens Health (Lond Engl). 2010;6(4):525-9.

17. Dahl K, Hvidman L, Jorgensen FS, Henriques C, Olesen F, Kjaergaard H, et al. First trimester Down syndrome screeening: pregnanct womens knowledge. Ultrasound Obstet Gynecol. 2011;38(2):145-51.
18. Allyse M, Minear AM, Berson E, Sridhar S, Rote M, Hung A, et al. Non-invasive prenatal testing: a review of international implementation and challenges. Int J Women's Health. 2015;7:113-26.

Cite this article as: Nambiar MK, Roopa PS, Nisha C, Kumar P. Downs syndrome and its screening: how aware are we? Int J Reprod Contracept Obstet Gynecol 2018;7:1186-90. 